\title{
The importance of programmed death ligand 1 gene expression, epidermal growth factor receptor gene mutations and serum epidermal growth factor receptor levels in Turkish non-small cell lung cancer patients
}

\author{
Türk küçük hücreli dışı akciğer kanseri hastalarında programlı ölüm ligandı 1 gen anlatımı, \\ epidermal büyüme faktörü reseptörü gen mutasyonları ve epidermal büyüme faktörü \\ reseptörü serum düzeylerinin önemi

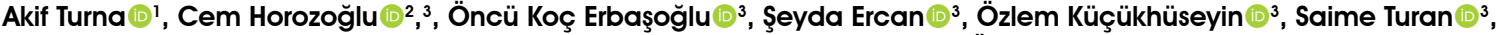 Mehmet Tolgahan Hakan $\mathbb{1}^{3,4}$, Hasan Volkan Kara ${ }^{1}{ }^{1}$, Elvin Hekimoğlu $\mathbb{1}^{5}$, Ümit Zeybek $\mathbb{D}^{3}$, Ender Coşkunpınar ${ }^{6}{ }^{6}$, Canan Cacına $\mathbb{1}^{3}$, Arzu Ergen $\mathbb{1}^{3}{ }^{3}$, ilhan Yaylım $\mathbb{1}^{3}$

Institution where the research was done:

Cerrahpaşa Medical Faculty, istanbul University, istanbul, Turkey

\author{
Author Affiliations: \\ 'Department of Thoracic Surgery, Cerrahpaşa Medical Faculty, İstanbul University, İstanbul, Turkey \\ ${ }^{2}$ Department of Medical Services and Techniques, Vocational School of Health Services, Istanbul Gelișim University, İstanbul, Turkey \\ ${ }^{3}$ Department of Molecular Medicine, Aziz Sancar Institute of Experimental Medicine, İstanbul University, İstanbul, Turkey \\ ${ }^{4}$ Department of Biology, Hitit University, Art and Science Faculty Çorum, Turkey \\ ${ }^{5}$ National Institutes of Health, Bethesda, USA \\ ${ }^{6}$ Department of Internal Medicine, ìstanbul University, istanbul Faculty of Medicine Istanbul, Turkey
}

\section{ABSTRACT}

Background: This study aims to investigate the possible relationships between epiderma growth factor receptor gene mutations, serum epidermal growth factor receptor levels, programmed death ligand gene expression levels and the risks and survivals of resectable nonsmall cell lung cancer patients.

Methods: Deoxyribonucleic acid isolation was performed from peripheral blood samples and tumor tissues. The mutation analysis was performed for epidermal growth factor receptor Programmed death ligand 1 gene expression levels were examined pathologically and histopathologically following the tissue tracing of 36 non-small cell lung cancer patients ( 29 males, 7 females; mean age 60.1 years; range, 41 to 79 years) and analyzed using real-time polymerase chain reaction. Epidermal growth factor receptor serum levels were assessed in all patients.

Results: As a result of mutation analyses in 21 patients $(28.5 \%$ of all adenocarcinoma patients), epidermal growth factor receptor mutation was determined in at least one exon in six patients. In epidermal growth factor receptor mutation detected patients, programmed death ligand 1 gene expression levels were associated with lymph node metastasis $(\mathrm{p}=0.036)$. However, epidermal growth factor receptor mutations were not statistically significantly associated according to histopathological examination ( $\mathrm{p}>0.05$ ). Of patients carrying exon 20 (c. $2303 \mathrm{G}>\mathrm{T}$ ) mutations, $25 \%$ had tumors with perineural invasion. There was a statistically significant association between exon 20 insertions and c.2303G $>\mathrm{T}$ and lymphatic invasion $(\mathrm{p}=0.02)$, lymph node metastasis and exon 20 insertions $(\mathrm{p}=0.03)$. Patients with lower serum epidermal growth factor receptor levels $(<400 \mathrm{pg} / \mathrm{mL})$ had better survival time than those with higher serum epidermal growth factor receptor levels $(\mathrm{p}=0.04)$.

Conclusion: Programmed death ligand 1 gene expression and epidermal growth facto receptor mutation might have a combined effect on non-small cell lung cancer. Programmed death ligand 1 gene expression in tumor pathology may also be a significant feature for tumor progression and tumorigenesis. Serum epidermal growth factor receptor levels seem to be associated with survival.

Keywords: Epidermal growth factor receptor; histopathology of tumors; lung cancer; programmed death ligand 1.
$\ddot{O} Z$

Amaç: Bu çalışmada epidermal büyüme faktörü reseptörü gen mutasyonları, epidermal büyüme faktörü reseptörü serum düzeyleri, programlı ölüm ligandı gen anlatım düzeyleri ve küçük hücreli dıșı akciğer kanseri hastalarının risk ve sağkalımları arasındaki olası ilişkiler araştırıldı.

Çalışma planı: Deoksiribonükleik asit izolasyonu periferik kan örnekleri ve tümör dokularından yapıldı. Epidermal büyüme faktörü reseptörü için mutasyon analizi yapıldı. Programlı ölüm ligandı 1 gen anlatım düzeyleri, 36 küçük hücreli dıșı akciğer kanseri hastasının (29 erkek, 7 kadın; ort. yaş 60.1 yıl; dağılım, 41-79 yıl) doku takibi sonrasında patolojik ve histopatolojik olarak incelendi ve gerçek zamanlı polimeraz zincir reaksiyonu kullanılarak analiz edildi. Tüm hastalarda epidermal büyüme faktörü reseptörü serum düzeyleri değerlendirildi.

Bulgular: Yirmi bir hastanın (tüm adenokarsinom hastalarının $\% 28.5$ 'i) mutasyon analizleri sonucunda, altı hastada en az bir ekzonda epidermal büyüme faktörü reseptörü mutasyonu saptandı. Epidermal büyüme faktörü reseptörü mutasyonu saptanan hastalarda, programlı ölüm ligandı 1 gen anlatım düzeyleri lenf nodu metastazı ile ilişkili idi $(\mathrm{p}=0.036)$. Diğer yandan, histopatolojik incelemeye göre epidermal büyüme faktörü reseptörü mutasyonları istatistiksel olarak anlamlı şekilde ilişkili değildi ( $>0.05$ ). 20. ekzon (c.2303G $>$ T) mutasyonları taşıyan hastaların \%25'inde perinöral invazyonlu tümörler vardı. 20. ekzona eklenmeler ve c. $2303 \mathrm{G}>\mathrm{T}$ ve lenfatik invazyon $(\mathrm{p}=0.02)$, lenf nodu metastazı ve 20. ekzona eklenmeler $(\mathrm{p}=0.03)$ arasında istatistiksel olarak anlamlı bir ilişki vardı. Daha düşük $(<400 \mathrm{pg} / \mathrm{mL})$ epidermal büyüme faktörü reseptörü serum düzeyleri olan hastaların sağkalım zamanı daha yüksek epidermal büyüme faktörü reseptörü serum düzeyleri olanlardan daha iyi idi $(\mathrm{p}=0.04)$.

Sonuc: Programlı ölüm ligandı 1 gen anlatımı ve epidermal büyüme faktörü reseptörü mutasyonu küçük hücreli dışı akciğer kanseri üzerinde birleşik bir etkiye sahip olabilir. Tümör patolojisinde programlı ölüm ligandı 1 gen anlatımı tümör ilerlemesi ve tümörigenez için de anlamlı bir nitelik olabilir. Epidermal büyüme faktörü reseptörü serum düzeyleri sağkalım ile ilişkili görünmektedir.

Anahtar sözcükler: Epidermal büyüme faktörü reseptörü; tümörlerin histopatolojisi; akciğer kanseri; programlı ölüm ligandı 1.

\section{Received: December 19, 2017 Accepted: March 01, 2018}

Correspondence: Akif Turna, MD. İstanbul Üniversitesi Cerrahpaşa Tıp Fakültesi Göğüs Cerrahisi Anabilim Dall, 34093 Şehremini, Fatih, ìstanbul, Turkey.

Tel: +90 212 - 4143327 e-mail: akif.turna@gmail.com

\section{Cite this article as:}

Turna A, Horozoğlu C, Koç Erbaşoğlu Ö, Ercan Ş, Küçükhüseyin Ö, Turan S, et al. The importance of programmed death ligand 1 gene expression, epidermal growth factor receptor gene mutations and serum epidermal growth factor receptor levels in Turkish non-small cell lung cancer patients. Turk Gogus Kalp Dama 2018;26(3):450-457. 
Lung cancer, as the leading cause of cancer deaths, is one of the most common types of cancers in the world. ${ }^{[1]}$ Although the incidence of lung cancer in the United States of America (USA) was reported to be decreasing steadily among cancer-related deaths, lung cancerrelated death rates were increased in some countries with increased cigarette consumption. ${ }^{[1]}$ In addition to proven risk factors such as cigarette smoking, various lines of evidence suggest that genetic factors contribute to genesis of non-small cell lung cancer (NSCLC). ${ }^{[2]}$ Thus, screening high-risk populations has become crucial for NSCLC to find effective therapy approaches as well as diagnosis at an early stage. ${ }^{[3]}$

The epidermal growth factor receptor (EGFR), a member of tyrosine kinase receptor of the ErbB family, which was aberrantly activated in many epithelial tumors, is one of the targeted molecules pioneer to the treatment of NSCLC. ${ }^{[4]}$ Epidermal growth factor receptor has been shown to be associated with proliferation of malignant cells, escape from apoptosis, cell migration and angiogenesis. ${ }^{[4]}$ Recent studies indicated that $10-15 \%$ of NSCLC patients have mutations at exon 18 to 21 corresponding to tyrosine kinase domain of EGFR gene. ${ }^{[4]}$ These mutations alter in patients of different countries depending on the individuals' haplotype, genetic predisposition and environmental or life style factors as for cigarette consumption.

Many studies that attempt to explain the biological mechanism of tyrosine kinase inhibitor sensitivity and resistance are reviewed. Interestingly, it was revealed that in non-smoker cases, EGFR gene mutations, particularly deletions and/or insertions at exon 19 are thought to be responsible for tyrosine kinase inhibition. ${ }^{[4,5]}$ On the other hand, the soluble, circulating form of EGFR levels were investigated as a potential biomarker for the risk of NSCLC. ${ }^{[6,7]}$

Recent studies focusing on immunotherapy revealed various immunosuppressive mechanisms including programmed death-1 (PD-1) receptor/programmed death ligand 1 (PD-L1) pathway, a common and complex pathway for escaping from immune system and hence resulting in tumor growth. ${ }^{[8]}$ Programmed death-1 receptor 1 is a transmembrane protein which has two important tyrosine-based motifs in its cytoplasmic domain that implicated in its immunosuppressive effects, expressed in immune cells including T, B and natural killer (NK) cellss. ${ }^{[8]}$ On the other hand, PD-L1 is a member of the B7 family of co-stimulatory/ co-inhibitory molecules of antigen presentation and expressed in a wide range of cell types, including cancer cells. ${ }^{[8,9]}$ It was shown that antibodies against both PD-1 and/or PD-L1 which blocks interactions between cancer cells and T-cells benefit NSCLC patients with good survival rates, low toxicity and long lasting responses. ${ }^{[9,10]}$

In this study, we aimed to investigate the possible relationships between EGFR gene mutations, serum EGFR levels, PDL-1 gene expression levels and the risks and survivals of resectable NSCLC patients.

\section{PATIENTS AND METHODS}

\section{Case samples}

This study was conducted at İstanbul University Cerrahpaşa Faculty of Medicine between January 2014 and December 2014 and included 36 patients (29 males, 7 females; mean age 60.1 years; range, 41 to 79 years), who were diagnosed with lung cancer in the department of thoracic surgery at the same faculty. The study protocol was approved by the Cerrahpaşa Faculty of Medicine Ethics Committee. A written informed consent was obtained from each patient. The study was conducted in accordance with the principles of the Declaration of Helsinki. All subjects were operated and their tissue and peripheral blood specimens were collected.

\section{Histopathological examinations}

Patients with lung cancer were diagnosed with radiological and routine pathological and histopathological examinations of the tissue. Parameters were recorded such as the results of the mediastinoscopy performed to determine the mediastinal lymph involvement, the performed operation, the last stage of the tumor according to the seventh staging system (pathologic Tumor, Node, Metastasis [pTNM] ${ }^{[11]}$ revealed as a result of the pathological examination of the resected tissue, the grade of the tumor detected in the pathological examination and vascular, lymphatic and perineural involvement. All patients underwent resectional surgery for $\mathrm{T}_{1}-\mathrm{T}_{4} \mathrm{~N}_{0} \mathrm{M}_{0}$ non-small cell lung cancer. Histologic slides from patients were analyzed according to the World Health Organization 2015 classification for NSCLC.$^{[12]}$ The preoperative workup included routine blood tests, pulmonary function tests with or without diffusion capacity of lung for carbon monoxide and ventilation-perfusion lung scan, and blood gas analysis. Fiberoptic bronchoscopy, computed tomographic scan of thorax, cranial magnetic resonance imaging, and positron emission tomography were performed in most patients. A systematic mediastinal lymphadenectomy or systematic lymph node sampling was performed in every patient, following lung resection (lobectomy 
in all patients). All patients underwent uniform staging to determine a final surgical-pathologic stage, based on information obtained through resection lymphadenectomy and pathology examination according to recent TNM staging system. ${ }^{[1]}$ The specimens were evenly planed with a cryostat. Sections (3 to $4 \mathrm{~mm}$ ) were sliced followed by hematoxylin and eosin staining. Special attention was given to tumor invasions to lymphatic, vascular vessels, and perineural structures. Tumor invasion to lymphatic and vascular vessels was described as tumor infiltrating vessels directly or tumor thromboses detected inside the vessels. The existence of perineural invasion was described when the tumor involved epineurium in the peritumoral tissue.

The surrounding tissue of the tumor without findings of macroscopic invasion was included in the study as the control group. Of the 36 patients, 21 (58.3\%), $10(27.8 \%)$, and two patients $(5.6 \%)$ were found to have adenocarcinoma, squamous cell carcinoma and adenocarcinoma with neuroendocrine differentiation respectively. One patient $(2.8 \%)$ was diagnosed to have large cell carcinoma and both neuroendocrine carcinoma.

Total deoxyribonucleic acid (DNA) and ribonucleic acid (RNA) isolation and complementary-deoxyribonucleic acid synthesis

Deoxyribonucleic acid extraction was carried out from the peripheral blood samples with the DNeasy Mini Kit (Qiagen Inc, Hilden, Germany). The tissues were inserted in the RNAlater ${ }^{\mathrm{TM}}$ (Invitrogen, Life Technologies, São Paulo, Brazil) in the liquid nitrogen until the extraction time. TRIzol ${ }^{\circledR}$ reagent (Invitrogen, Carlsbad, CA, USA) was used for the homogenization of the tissues and RNA extraction was carried out with TRIzol reagent. After RNA6000 Nano Kit ${ }^{\circledR}$ (Agilent Technologies, Santa Barbara, CA, USA) and a 2100 Bioanalyzer $^{\circledR}$ (Agilent Technologies) were used for the evaluation of the RNA's amount and quality, items with a higher RNA integrity level were recorded at the final stage of the evaluation. Following the equalization of the concentrations of the RNA samples that were extracted separately from the tumor and surrounding tissue, complementary DNA (c-DNA) synthesis was carried out with the RevertAid First Strand cDNA Fermentas ${ }^{\circledR}$ Synthesis Kit (Thermo Fisher Scientific, Waltham, MA, USA).

\section{Microarray analysis}

In our study, the mutation analysis was performed in the DNA samples with the INFINITI ${ }^{\circledR}$ EGFR Assay (Autogenomics, Carlsbad, CA, USA) kit used with
BioFilmChip, which involved the spotted regions specific to the EGFR exon mutations and INFINITI ${ }^{\circledR}$ Analyzer (Autogenomics, Carlsbad, CA, USA) device. Multiplex polymerase chain reaction (PCR) was first carried out according to the assay and then hybridization was performed with fluorescent label incorporation using allele specific primer extension. Then, the samples were washed with irrigation solutions of the microarray platform chip and dried in the desiccator. The signal detection was performed with the INFINITI ${ }^{\circledR}$ Analyzer and evaluated with the INFINITI $^{\circledR}$ software.

\section{Real time polymerase chain reaction (RT-PCR)}

Stratagene Mx3005P (Agilent Technologies) was used for the confirmation of the results of the mutation analysis and for the investigation of the gene expression of the PD-L1 levels in the tissues. Primers, which were created for the compatibility from sequence exon boundaries were used for the RT-PCR. Gene amplification in the RT-PCR was identified with the Fast-Plus EvaGreen ${ }^{\circledR}$ Master Mix (Bio-Rad, Hercules, CA, USA).

Regarding each target and housekeeping gene, an independent PCR reaction was selected, while a special study structure was chosen for triplet repeats.

Primer was designed according to Bianco et al. ${ }^{[13]}$ a 155bp length amplicon was aimed to be amplified with the following set of primers $\left(5^{\prime}\right.$ to $\left.3^{\prime}\right)$ : PDL-1 F: CAA AGA ATT TTG GTT GTG GA, R: AGC TTC TCC TCT CTC TTG GA; GAPDH F: TGC ACC ACC AAC TGC TTA GC R: GGC ATG GAC TGT GGT CAT GAG. Standard curves were created to provide the amplification efficiency. The examination of the melting curves showed only one peak considering the primers.

Fast Plus EvaGreen ${ }^{\circledR}$ Master Mix $(12 \mu \mathrm{L})$ involved $3 \mu \mathrm{L}$ c-DNA. $6 \mu \mathrm{L}$ of the Fast Plus EvaGreen ${ }^{\circledast}$ Master Mix and $3 \mu \mathrm{L}$ of the forward and reverse primers mixture were processed to a concentration of $200 \mathrm{nM}$. PCR process: 2 minutes at $50^{\circ} \mathrm{C}$, than, 10 minutes polymerase activation at $95^{\circ} \mathrm{C}$ and 35 cycles at $95^{\circ} \mathrm{C}$ for 15 seconds and $60^{\circ} \mathrm{C}$ for one minute.

The gene expression levels of the target genes were worked out with the $\Delta \Delta \mathrm{Ct}$ method and the obtained $\Delta \mathrm{Ct}$ value was normalized with a calibrator. Following the removal of the samples with extreme gene expression, the calibrator was selected considering the variables like the lowest $\mathrm{Ct}$ level and the geometric and arithmetic mean values. The value of the calibrator sample was installed to 1 . The value chosen as the calibrator was only used for 
the normalization and not included in the statistical analysis.

\section{Statistical analyses}

Statistical evaluation was carried out with IBM SPSS version 20.0 software (IBM Corp., Armonk, NY, USA) and Graphpad Prism (Graphpad, LaJolla, CA, USA). Fisher's exact test was used for the analysis of the clinical and histopathological parameters of the mutation data. The analysis of the mean values and intragroup distributions in both groups displayed a non-normal distribution. As our sample size was limited, we used Mann-Whitney $\mathrm{U}$ test as a non-parametric test. Patient survival was expressed by actuarial analysis according to the method of Kaplan and Meier, and differences in survival were determined using the log-rank test in the univariate analysis. The patients were followed-up with the database of the Central Civil Registration System and phone. The mean follow-up time was 26 months (range 12-48 months). For all analyses, $\mathrm{p}<0.05$ was considered as statistically significant.

\section{RESULTS}

There were 21 patients (58.3\%) with adenocarcinoma. Clinical and clinicopathological data of our patients are shown in Table 1. No statistically significant association was detected between the PD-L1 gene expression and age, gender, histological typing, pathological staging or tumor differentiation in respect of EGFR mutation $(\mathrm{p}>0.05)$.

On the other hand, serum EGFR levels were found to be statistically significantly higher in alcohol users than non-alcohol users ( $\mathrm{p}=0.014)$. Similarly, PD-L1 gene expression level was statistically significantly higher in patients with lymph node metastasis than in patients without lymph node metastasis $(\mathrm{p}=0.036)$. Despite the lack of any statistical significance, mean PD-L1 expression level was $4.22 \pm 1.62$ in patients with early stage $\left(T_{1}\right.$ and $\left.T_{2}\right)$ lung cancer whereas it was $3.02 \pm 2.33$ in patients with extended stage $\left(\mathrm{T}_{3}\right.$ and $\left.\mathrm{T}_{4}\right)(\mathrm{p}=0.1)$.

Missense mutations of EGFR were detected in six of $21(28.6 \%)$ adenocarcinoma patients. Although

Table 1. Level of programmed death ligand 1 and epidermal growth factor receptor expression with regard to clinical and pathological parameters

\begin{tabular}{|c|c|c|c|c|}
\hline \multirow[b]{2}{*}{ Characteristics } & \multicolumn{2}{|c|}{ PD-L1 gene expression levels } & \multicolumn{2}{|c|}{ Serum EGFR levels } \\
\hline & Mean \pm SE & $p$ & Mean \pm SE & $p$ \\
\hline \multicolumn{5}{|l|}{ Gender } \\
\hline Male & $4.1 \pm 1.5$ & \multirow{2}{*}{0.727} & $341.7 \pm 34.6$ & \multirow{2}{*}{0.929} \\
\hline Female & $2.0 \pm 1.8$ & & $353.0 \pm 60.0$ & \\
\hline \multicolumn{5}{|l|}{ Cigarette smoking } \\
\hline$<50$ pack (year) & $3.7 \pm 1.4$ & \multirow{2}{*}{0.776} & $337.2 \pm 42.1$ & \multirow{2}{*}{0.868} \\
\hline$>50$ pack (year) & $4.1 \pm 3.4$ & & $353.9 \pm 43.8$ & \\
\hline Alcohol usage & $2.9 \pm 1.3$ & \multirow{2}{*}{0.497} & $417.2 \pm 22.7$ & \multirow{2}{*}{0.014} \\
\hline No alcohol usage & $6.2 \pm 3.0$ & & $281.6 \pm 46.4$ & \\
\hline \multicolumn{5}{|l|}{ Histology } \\
\hline Squamous carcinoma & $4.9 \pm 3.6$ & \multirow{2}{*}{0.500} & $340.9 \pm 55.4$ & \multirow{2}{*}{0.657} \\
\hline Adenocarcinoma & $3.0 \pm 1.5$ & & $364.4 \pm 45.1$ & \\
\hline \multicolumn{5}{|l|}{ Perineural invasion } \\
\hline Present & $5.8 \pm 1.9$ & \multirow{2}{*}{0.082} & $337 \pm 42.8$ & \multirow{2}{*}{0.628} \\
\hline Absent & $1.4 \pm 1.1$ & & $350.8 \pm 45.6$ & \\
\hline \multicolumn{5}{|c|}{ Lymph node metastasis $\left(\mathrm{N}_{1}-\mathrm{N}_{2}\right)$} \\
\hline $\mathrm{N}_{1}-\mathrm{N}_{2}$ & $4.6 \pm 1.4$ & \multirow{2}{*}{0.036} & $376.2 \pm 38.1$ & \multirow{2}{*}{0.456} \\
\hline $\mathrm{N}_{0}$ & $0.0 \pm 0.0$ & & $303.7 \pm 48.3$ & \\
\hline \multicolumn{5}{|l|}{ T Stage } \\
\hline $\mathrm{T}_{1}-\mathrm{T}_{2}$ & $4.2 \pm 1.6$ & \multirow{2}{*}{0.927} & $366.4 \pm 37.8$ & \multirow{2}{*}{0.267} \\
\hline $\mathrm{T}_{3}-\mathrm{T}_{4}$ & $3.0 \pm 2.3$ & & $293.6 \pm 50.2$ & \\
\hline
\end{tabular}

PD-L1: Programmed death ligand 1; EGFR: Epidermal growth factor receptor; SE: Standard error. 
the presence of EGFR mutation was not statistically significant in terms of histopathology, perineural invasion was not observed in $75 \%$ of patients carrying exon 20 (c.2303G $>\mathrm{T}$ ) mutations. On the other hand, lymphatic invasion was demonstrated in all patients carrying exon 20. Similarly, lymphatic invasion was detected to be positive in patients carrying exon 20 (c.2303G $>\mathrm{T}$ ) and exon 20 insertions (Exon20ins). Exon20ins were determined in all six patients with lymph node involvement. However, exon 19 deletion (Exon19del) was detected in early tumor stage. There was a statistically significant association between Exon20ins and c.2303G $>\mathrm{T}$ and lymphatic invasion $(\mathrm{p}=0.02)$, lymph node metastasis and Exon20ins $(p=0.03)$. When we investigated mutations for tumor stages, we observed that $67.7 \%$ of Exon20ins were found in early stages and $33.3 \%$ were in late stage. No mutation was detected in one case with distant organ metastasis.

Relationship between PD-L1 expression levels and mutations in exon 18-19-20-21 was not statistically significant in normal and tumor tissues of patients $(p>0.05)$. Although the PD-L1 gene expression was slightly higher in the tumor tissue compared to the control tissue, there was no statistically significant difference $(\mathrm{p}=0.8089)$.

In our study, there was no significant difference in survival rates between the cases with or without EGFR mutations $(p=0.21)$. Mean levels of serum EGFR of non-small cell lung cancer patients and healthy control group were calculated as $341.49 \pm 20.90 \mathrm{pg} / \mathrm{mL}$ and $574.9 \pm 18.18 \mathrm{pg} / \mathrm{mL}$, respectively, with a statistically significant difference $(\mathrm{p}<0.001)$. According to the EGFR levels, survival rate at three years was $45 \%$ and mean survival time was 19 (95\% confidence interval: 14-29 months) and 23 months (95\% confidence

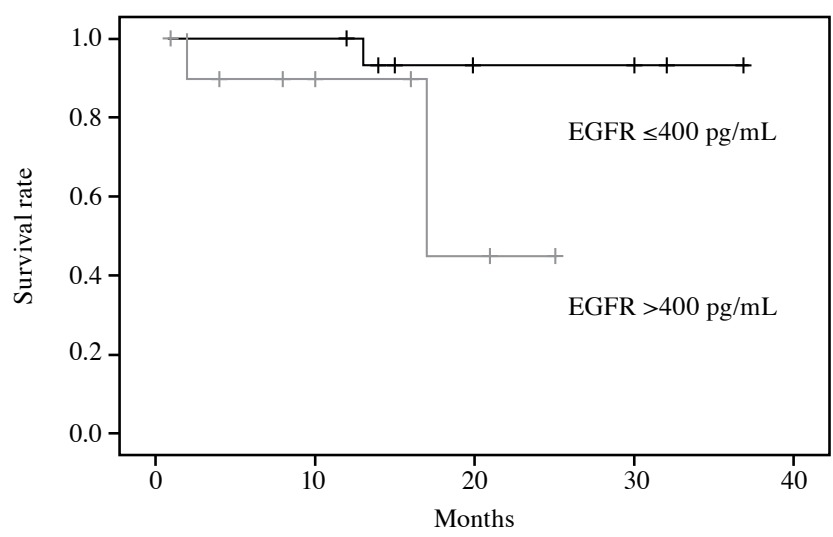

Figure 1. Survival of patients according to serum epidermal growth factor receptor levels. interval: 18-29 months) in patients with serum EGFR levels higher or lower than $400 \mathrm{pg} / \mathrm{mL}$, respectively. The patients with lower serum EGFR $(<400 \mathrm{pg} / \mathrm{mL})$ had better survival time than those with higher serum EGFR levels ( $\mathrm{p}=0.04)$ (Figure 1).

\section{DISCUSSION}

In this study, we detected that serum EGFR level is associated with survival in NSCLC patients. Lung cancer is the main cause of cancer-related mortality worldwide, with five-year survival rate of approximately $18 \% .^{[1]}$ Approximately $80 \%$ of lung cancer cases were diagnosed with NSCLC according to pathological findings. ${ }^{[1]}$ Genome-wide molecular-profiling studies have provided compelling evidence related to the characteristic genetic/ epigenetic alterations associated with lung cancers. ${ }^{[2]}$ These characteristically distinct molecular features can be used for high-resolution lung cancer classification and to predict patient outcomes to pave the way towards molecular-guided, individualized treatment. EGFR is one of the important markers regarding the diagnosis, prognosis and the therapy of lung cancer.

Approximately 10 to $15 \%$ of Caucasian patients with pulmonary adenocarcinoma had EGFR activating mutations (exons 18-21). ${ }^{[4,5]}$ Deletions in exon 19 and point mutation at the position 858 in exon 21 (L $858 \mathrm{R}$ ) are among the most common mutations and constitute approximately $85 \%-90 \%$ of all EGFR mutations. ${ }^{[4]}$ These mutations are called "sensitizing mutations" and are susceptible to EGFR tyrosine kinase inhibitors (TKIs). 10\%-15\% of cases had the so-called uncommon EGFR mutations and presented variable TKI sensitivity. ${ }^{[2]}$ Mutated receptors demonstrated essential, ligand-independent tyrosine kinase activity, which had a stimulating effect on many intracellular signaling cascades (e.g. STAT, RAS-RAF-ERK, PI3K/ Akt, Src kinase, phospholipase $\mathrm{C} \gamma$ pathways). The activation of these pathways had an important role in the progression of the tumor and therefore in the survival rates of patients. ${ }^{[3]}$

Programmed death-1 receptor, a vital immune checkpoint receptor, is strongly expressed in the activated T-cells and in certain tumors like NSCLC. ${ }^{[9]}$ Following the interaction between PD-1 and PD-L1, the immune reaction is suppressed, ${ }^{[9,10]}$ and the severity of the inflammation is controlled. More importantly, the interaction between PD-1 and PD-L1 exerted inhibitory effects on the activity of T-cells, which significantly impaired tumor killing activity of T cells..$^{[10]}$

Very few studies have focused on the correlation between PDL-1 and EGFR, although EGFR is highly expressed in the tumor tissue. ${ }^{[14]}$ 
Paulsen et al. ${ }^{[15]}$ performed a histopathological examination of PD-1 and PD-L1 in NSCLC and emphasized their prognostic significance. They also emphasized that co-evaluation of PD-1 and PD-L1 was critical for an accurate TNM staging and prognosis. ${ }^{[14]}$

Moreover, Aguiar et al. ${ }^{[16]}$ showed that nivolumab (inhibited PD-1 and PD-L1) treatment had different bioavailability and outcomes in PD-L1 negative and positive cases. Furthermore, although Patel et al. ${ }^{[17]}$ investigated vesicular stomatitis virus (VSV), they also reported positive results related to anti-tumor effect and tumor immunity due to increased PD-L1 expression after the interferon- $\beta$ treatment.

Monsó et al. ${ }^{[18]}$ conducted a comprehensive study focused on the histopathological and molecular findings and stated that the TNM classification should be improved in respect of prognosis and predictivity in stage I/IIp NSCLC. Additionally, this study showed that although previous studies with PD-L1 had limited number of subjects, they provided enough data, which could be interpreted in favor of a correlation between the survival rate and mesothelioma PD-L1 expression. ${ }^{[18]}$ Another study that was conducted by Lee et $a .^{[19]}$ on functional polymorphism of PD-L1 and results suggested that the PD-L1 variants were important in early stage NSCLC regarding the followup of the prognosis.

Additionally, Lafuente-Sanchis et al. ${ }^{[20]}$ conducted a study with 78 patients in order to reveal the importance of PD-L1 and PD-1 gene expression. Although they could not demonstrate any correlation between the PD-L1 gene expression and age, gender, smoking habits, histological type, pathological stage or tumor differentiation degree in NSCLC cases, they suggested that the PD-L1 overexpression might be correlated with low survival rate and high tumor differentiation. ${ }^{[19]} \mathrm{We}$ found that lymph node involvement was associated with PD-L1 expression which is an important prognostic factor in resected NSCLC patients. The data obtained in the study of Sumitomo et al. ${ }^{[2]}$ on mitogen-activated protein kinase (MAPK) pathway displayed that PD-L1 was important in the MAPK pathway and like in our study, the EGFR mutations were significantly more common in cases with high PD-L1 expression.

As the importance of PD-L1 is gradually understood regarding clinical staging, treatment and prognosis, functional and epidemiological studies are still on-going. In our study, we investigated the PD-L1 expression levels not only in NSCLC patients with EGFR mutation but also in NSCLC patients without EGFR mutation. The results of our investigation were in line with the findings of the study conducted by Lafuente-Sanchis et al. ${ }^{[19]}$

In our study, we investigated the EGFR mutations in 36 NSCLC patients, among whom 21 had adenocarcinoma and six had missense mutation. We searched for any correlation between PD-L1 gene expression and age, gender, histological typing, pathological staging and tumor differentiation in respect of EGFR mutation; however, we could not detect any statistically significant correlation. In addition, we investigated PD-L1 gene expression level between tumor tissue and control tissue but we could not demonstrate any statistical significance, although the gene expression was higher in the tumor tissue compared to the control tissue.

Although the presence of EGFR mutation was not statistically significant in terms of histopathology, perineural invasion was not observed in $75 \%$ of patients carrying exon 20 (c.2303G $>\mathrm{T}$ ) mutations; on the other hand, lymphatic invasion was demonstrated in all patients carrying exon 20. Similarly, lymphatic invasion was detected to be positive in patients carrying exon 20 (c.2303G $>\mathrm{T}$ ) and Exon20ins. Exon20ins were determined in all six patients with lymph node involvement. However, Exon19del was detected in early tumor stage. When we investigated mutations for tumor stages, we observed that $67.7 \%$ of Exon20ins were found in early stages and $33.3 \%$ in late stage. Relationship between PD-L1 expression levels and mutations in exon 18-19-20-21 was not found to be statistically significant in normal and tumor tissues of patients.

To our knowledge, the association between EGFR serum levels and survival has been reported previously. Jantus-Lewintre et al. ${ }^{[22]}$ investigated the role of levels of EGFR in NSCLC patients. However, they were not able to find any association between the levels and survival. The possible speculation in this respect could be that, higher EGFR levels may be surrogate of higher proliferation, angiogenesis and more aggressive tumor biology. However, we were not able to find any correlation between the EGFR levels and histopthological parameters of the patients.

We also found that alcohol usage was associated with higher serum EGFR levels. There has been no evidence explaining this association. Alcohol might have increased the shedding of EGFR molecules into the bloodstream. Lu et al. ${ }^{[23]}$ demonstrated that alcohol could be associated with apoptosis and EGFR degradation in lung cancer cell line. However, further studies are warranted to clarify this issue. 
The most important limitation of our study was the small sample size. Our objective for future studies is to increase the tumor and control tissues and to investigate the PD-L1 gene expression levels in the lymph node samples in patients with EGFR mutation with immunohistochemical and molecular parameters.

In conclusion, our study has a specific value regarding the demonstration of the epidermal growth factor receptor mutations in the Turkish population and programmed death ligand 1 gene expression levels. In addition, we believe that the recorded data about patients with epidermal growth factor receptor mutation and high programmed death ligand 1 expression will contribute to the studies in the future, although we could not demonstrate any statistical correlation with lymph node involvement.

\section{Declaration of conflicting interests}

The authors declared no conflicts of interest with respect to the authorship and/or publication of this article.

\section{Funding}

The present work was supported by the Research Fund of Istanbul University. Project No. 20783, 14516.

\section{REFERENCES}

1. Siegel RL, Miller KD, Jemal A. Cancer statistics, 2016. CA Cancer J Clin 2016;66:7-30.

2. Okazaki I, Ishikawa S, Ando W, Sohara Y. Lung Adenocarcinoma in Never Smokers: Problems of Primary Prevention from Aspects of Susceptible Genes and Carcinogens. Anticancer Res 2016;36:6207-24.

3. Dhanasopon AP, Kim AW. Lung Cancer Screening and Its Impact on Surgical Volume. Surg Clin North [Am] 2017;97:751-762.

4. Piotrowska Z, Sequist LV. Epidermal Growth Factor Receptor-Mutant Lung Cancer: New Drugs, New Resistance Mechanisms, and Future Treatment Options. Cancer J 2015;21:371-7.

5. Scaltriti M, Baselga J. The epidermal growth factor receptor pathway: a model for targeted therapy. Clin Cancer Res 2006;12:5268-72.

6. Romero-Ventosa EY, Blanco-Prieto S, González-Piñeiro AL, Rodríguez-Berrocal FJ, Piñeiro-Corrales G, Páez de la Cadena M. Pretreatment levels of the serum biomarkers CEA, CYFRA 21-1, SCC and the soluble EGFR and its ligands EGF, TGF-alpha, HB-EGF in the prediction of outcome in erlotinib treated non-small-cell lung cancer patients. Springerplus 2015;4:171.

7. Lococo F, Paci M, Rapicetta C, Rossi T, Sancisi V, Braglia L, et al. Preliminary Evidence on the Diagnostic and Molecular Role of Circulating Soluble EGFR in Non-Small Cell Lung Cancer. Int J Mol Sci 2015;16:19612-30.

8. Arasanz H, Gato-Cañas M, Zuazo M, Ibañez-Vea M, Breckpot K, Kochan G, et al. PD1 signal transduction pathways in T cells. Oncotarget 2017;8:51936-51945.
9. Bartee E, Li Z. In vivo and in situ programming of tumor immunity by combining oncolytics and PD-1 immune checkpoint blockade. Exp Hematol Oncol 2017;6:15.

10. Shien K, Papadimitrakopoulou VA, Wistuba II. Predictive biomarkers of response to PD-1/PD-L1 immune checkpoint inhibitors in non-small cell lung cancer. Lung Cancer 2016;99:79-87.

11. Groome PA, Bolejack V, Crowley JJ, Kennedy C, Krasnik M, Sobin LH, et al. The IASLC Lung Cancer Staging Project: validation of the proposals for revision of the T, N, and $\mathrm{M}$ descriptors and consequent stage groupings in the forthcoming (seventh) edition of the TNM classification of malignant tumours. J Thorac Oncol 2007;2:694-705.

12. Travis WD, Brambilla E, Nicholson AG, Yatabe Y, Austin JHM, Beasley MB, et al. The 2015 World Health Organization Classification of Lung Tumors: Impact of Genetic, Clinical and Radiologic Advances Since the 2004 Classification. J Thorac Oncol 2015;10:1243-1260.

13. Bianco R, Shin I, Ritter CA, Yakes FM, Basso A, Rosen N, et al. Loss of PTEN/MMAC1/TEP in EGF receptor-expressing tumor cells counteracts the antitumor action of EGFR tyrosine kinase inhibitors. Oncogene 2003;22:2812-22.

14. Won YW, Han JY, Lee GK, Park SY, Lim KY, Yoon KA, et al. Comparison of clinical outcome of patients with non-small-cell lung cancer harbouring epidermal growth factor receptor exon 19 or exon 21 mutations. J Clin Pathol 2011;64:947-52.

15. Paulsen EE, Kilvaer TK, Khanehkenari MR, Al-Saad S, Hald SM, Andersen S, et al. Assessing PDL-1 and PD-1 in Non-Small Cell Lung Cancer: A Novel Immunoscore Approach. Clin Lung Cancer 2017;18:220-233.e8.

16. Aguiar PN Jr, Santoro IL, Tadokoro H, de Lima Lopes G, Filardi BA, Oliveira $\mathrm{P}$, et al. A pooled analysis of nivolumab for the treatment of advanced non-small-cell lung cancer and the role of PD-L1 as a predictive biomarker. Immunotherapy 2016;8:1011-9.

17. Patel MR, Jacobson BA, Ji Y, Drees J, Tang S, Xiong K, et al. Vesicular stomatitis virus expressing interferon- $\square$ is oncolytic and promotes antitumor immune responses in a syngeneic murine model of non-small cell lung cancer. Oncotarget 2015;6:33165-77.

18. Monsó E, Montuenga LM, Sánchez de Cos J, Villena C. Biological Marker Analysis as Part of the CIBERES-RTIC Cancer-SEPAR Strategic Project on Lung Cancer. Arch Bronconeumol 2015;51:462-7.

19. Lee SY, Jung DK, Choi JE, Jin CC, Hong MJ, Do SK, et al. Functional polymorphisms in PD-L1 gene are associated with the prognosis of patients with early stage non-small cell lung cancer. Gene 2017;599:28-35.

20. Lafuente-Sanchis A,Zúñiga Á,Estors M, Martínez-Hernández NJ, Cremades A, Cuenca M, et al. Association of PD-1, PD-L1, and CTLA-4 Gene Expression and Clinicopathologic Characteristics in Patients With Non-Small-Cell Lung Cancer. Clin Lung Cancer 2017;18:e109-e116.

21. Sumimoto H, Takano A, Teramoto K, Daigo Y. RASMitogen-Activated Protein Kinase Signal Is Required for Enhanced PD-L1 Expression in Human Lung Cancers. PLoS One 2016;11:e0166626. 
22. Jantus-Lewintre E, Sirera R, Cabrera A, Blasco A, Caballero C, Iranzo V, et al. Analysis of the prognostic value of soluble epidermal growth factor receptor plasma concentration in advanced non-small-cell lung cancer patients. Clin Lung Cancer 2011;12:320-7.
23. Lu X, Yang L, Lu C, Xu Z, Qiu H, Wu J, et al. Molecular Role of EGFR-MAPK Pathway in Patchouli Alcohol-Induced Apoptosis and Cell Cycle Arrest on A549 Cells In Vitro and In Vivo. Biomed Res Int 2016;2016:4567580. 